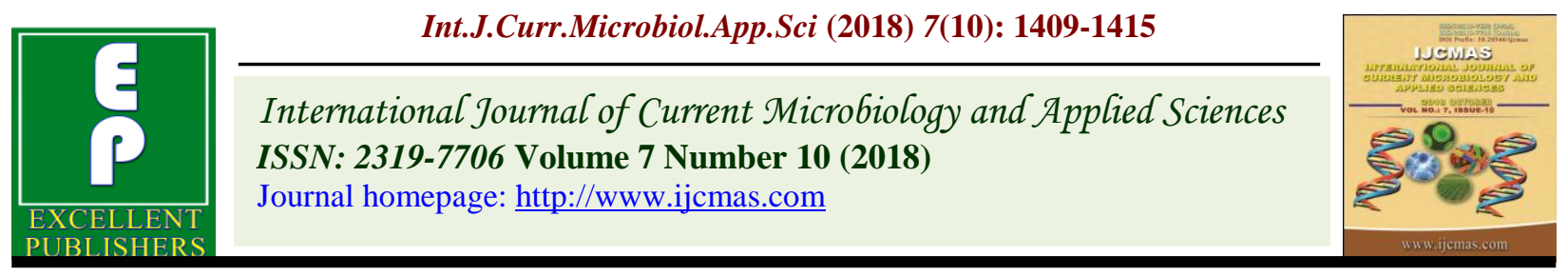

Original Research Article

https://doi.org/10.20546/ijcmas.2018.710.156

\title{
Screening Somaclones of Ginger (Zingiber officinale Rosc.) for Yield Attributes and Yield
}

\author{
Nimisha Mathews" and K. Krishnakumary \\ College of Horticulture, Department of Plantation Crops and Spices, Kerala Agricultural \\ University, Thrissur 680656, Kerala, India \\ *Corresponding author
}

\section{Keywords}

Ginger,

Somaclones, Yield and Horticulture

Article Info

Accepted:

12 September 2018

Available Online:

10 October 2018

\section{A B S T R A C T}

The experiment was taken up to elicit the information on yield attributes and yield of different ginger (Zingiber officinale Rosc.) somaclones. Ten somaclones of ginger were evaluated in RBD with three replications during 2015-18 at College of Horticulture, Kerala Agricultural University, Thrissur district, Kerala. The growth performance of ten somaclones indicated significant variation at all the stages of crop growth. The somaclones SE 86102 (16.00 days) and SE 8626 (16.33 days) registered least number of days for sprouting. Among the vegetative characters studied, the maximum plant height $(107.38 \mathrm{~cm})$ was recorded by the somaclone SE 86102 which was significantly superior to other somaclones and check varieties. Somaclone CHP 118 recorded maximum number of tillers (20.33) and number of leaves per shoot (28.67). The highest leaf area was recorded by C 8632 with a value of $62.12 \mathrm{~cm}^{2}$. Among the rhizome characters recorded, the somaclone CHP 118 gave highest number of primary rhizomes (4.83) which was on par with SE 8626 (4.33) and C 8632 (4.08). The highest number of secondary rhizome was recorded by CHP 118 (10.33) which was on par with SE 8626 (10.06) and C 8632 (10.01). Weight of mother rhizome was the highest in the somaclone SE 8642 (11.00 g) and CHP 118 (10.67 g). Similarly, weight of primary rhizome was highest in SE $8642(15.73 \mathrm{~g})$, SE 8626 $(15.07 \mathrm{~g})$ and CHP $118(14.86 \mathrm{~g})$. Weight of secondary rhizome was highest in SE $8626(13.20 \mathrm{~g})$ and SE $8642(12.33 \mathrm{~g})$. The highest fresh rhizome yield per plant was recorded by somaclone CHP 118 (274.13 g), SE 8626 (266.67 g), C 8632 (259.67 g) and SE $8642(251.67 \mathrm{~g})$ at full maturity. The highest yield per plot was recorded by somaclone CHP $118(8.77 \mathrm{~kg})$, SE $8626(8.54 \mathrm{~kg})$, C $8632(8.31 \mathrm{~kg})$ and SE 8642 $(8.06 \mathrm{~kg})$. The fresh rhizome yield per hectare was greater than $30 \mathrm{t}$ per hectare and it was maximum in CHP 118 (35.08 t), SE 8626 (34.16 t), C 8632 (33.24 t) and SE 8642 (32.24 t). It is concluded that somaclones were highly variable in their performance, yield and yield. Four somaclones viz., CHP 118, SE 8626, C 8632 and SE 8642 were identified as high yielders from their upstanding performance though out the growing period with highest yield in CHP 118. This can be due to more number of tillers, leaves per shoot and rhizomes and also weight of primary, secondary and mother rhizomes. 


\section{Introduction}

Ginger is an important commercial spice crop grown in India for its culinary and wide range of medicinal uses and is considered as an essential component of the kitchen pharmacy. It belongs to the family Zingiberaceae, native of South East Asia. It is a tropical and subtropical perennial herb 'generally recognized as safe' by the Food and Drug Administration (FDA) of the United States and has gained considerable attention as a botanical dietary supplement in developed countries, opening ample export potential. Somaclonal variations act as a major source of variability for crop improvement in ginger (Shylaja et al., 2010 and Dev, 2013). Evaluation of somaclones derived from two polyploids (Z-0-78 and Z-086) and a triploid cultivar Himachal Pradesh (generated through indirect organogenesis and embryogenesis) indicated that somaclones are superior to conventionally propagated plants for various growth and yield parameters (Kurian, 2010).The present investigation was carried out with the objective of evaluating somaclones in ginger for variability in performance, yield and yield attributes.

\section{Materials and Methods}

Somaclones developed through indirect methods of regeneration from two induced polyploids of ginger (Z-0-78 from 'Himachal Pradesh' treated with $0.25 \%$ colchicine by injection method and Z-0-86 from Rio-deJaneiro treated with $0.1 \%$ colchicine by hole method) and diploid cultivar 'Himachal Pradesh' formed the base material for the study (Table 1). Ten such somaclones of ginger viz., SE 86 26, SE 86 83, C 86 26, CHP 118, C 78 284, SE 86 102, SE 86 42, C 86 32, CHP 99 and CHP 282 were selected for the study along with three check varieties (Rio- de -Janeiro, Himachal and Aswathy). The experimental site was located in the farm of Department of Plantation Crops and Spices,
College of Horticulture, Thrissur, Kerala. The experiment was laid out in a Randomized Block Design with three replications in plot size $2.0 \times 1.0 \mathrm{~m}^{2}$ at the spacing of $25.0 \mathrm{~cm} \times$ $25.0 \mathrm{~cm}$. The field was prepared and planting was done in the last week of May and maintained as per Package of practice recommendations of Kerala Agricultural University (KAU, 2011).

Five plants per replication were selected at random and studied for growth characters. The crop was harvested at full maturity, indicated by withering of above ground parts. The harvested rhizomes were cleaned after removing roots and rhizome characters were recorded. The fresh rhizome yields per plant and per plot were recorded and per hectare yield was computed.

\section{Results and Discussion}

\section{Plant characters}

Ten ginger somaclones and three check varieties exhibited variation in number of days for sprouting and plant characters viz., plant height, number of tillers, number of leaves per shoot, and leaf area (Table 2).

Early sprouting was observed in all three check varieties and also in the somaclones SE 86102 (16.00 days) and SE 8626 (16.33 days). Released variety Aswathy took only 14 days for sprouting whereas, C 8626 and CHP 99 took 23 days to sprouting. Shadap et al., (2013) have reported similar result confirming early and complete sprouting in a shorter period when ginger planted in May and June.

Plant height of ginger somaclones varied between 72.42 to $107.38 \mathrm{~cm}$. The somaclone SE 86102 recorded the highest plant height $(107.38 \mathrm{~cm})$ which was significantly superior to other somaclones and check varieties. The lowest plant height was recorded in C 78284 
$(75.42 \mathrm{~cm})$ and Aswathy $(72.55 \mathrm{~cm})$. Similar variability in plant height of ginger somaclones was reported by Iwo et al., (2011) and Dev (2013).

The number of tillers per plant varied significantly among ginger somaclones.

The somaclone CHP 118 recorded the highest values for number of tillers per plant (20.33) followed by SE 8626 (18.01) and SE 8642 (17.97) and the lowest was for the somaclone CHP 99 (11.23) and the check varieties Himachal (11.43) and Rio- de -Janeiro (11.56). Variability in number of tillers in ginger genotypes was reported by Dev et al., (2016) and Surendra Babu et al., (2017).

The number of leaves per shoot among the somaclones varied between 16.43 and 28.67. The somaclone CHP 118 recorded the highest number of leaves per shoot (28.67) and was on par with SE 8626 (28.33). Lowest number of leaves per shoot (16.43) in the somaclones $\mathrm{C}$ 8626 (16.43) followed by CHP 99(16.87) and CHP 282 (16.93). Karthik et al., (2017) reported that the number of leaves per tiller ranged from 12.02 (T9- Acc-723) to 20.07 (T5-Acc-219) among the different germplasm studied.

Fig.1 Yield of ginger somaclones (t/ha)

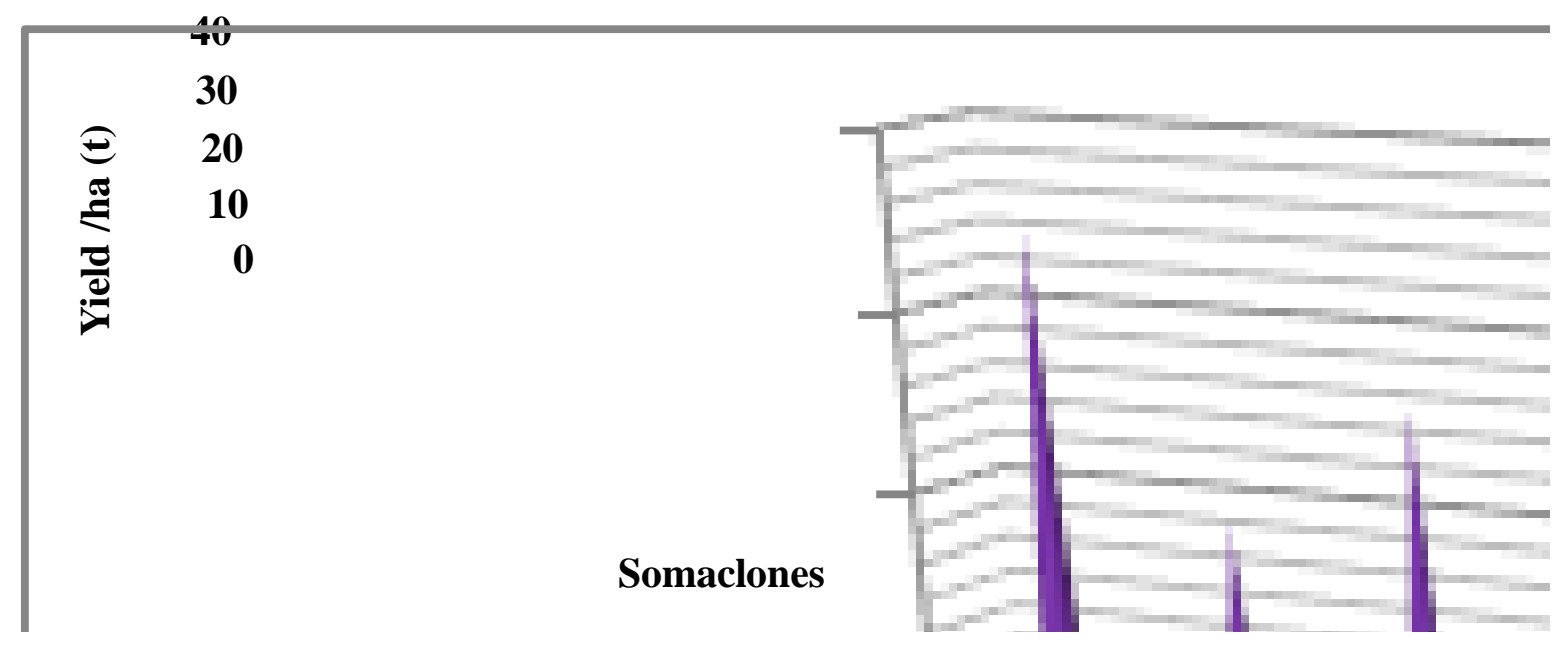

Table.1 Details of somaclones selected for the study

\begin{tabular}{|r|c|c|}
\hline Somaclones & Parents & Mode of regeneration \\
\hline C 86 26 & Z-0-78 & Indirect organogenesis \\
\hline C 86 32 78284 & Z-0-86 & \\
\hline CHP 282 & Himachal & \\
\hline CHP 118 & & \\
\hline CHP 99 & & Indirect embryogenesis \\
\hline SE 86 83 & Z-0-86 & \\
\hline SE 86 26 & & \\
\hline SE 86 42 & & \\
\hline SE 86 102 & & \\
\hline
\end{tabular}




\section{Int.J.Curr.Microbiol.App.Sci (2018) 7(10): 1409-1415}

Table.2 Morphological characters of ginger somaclones at 6 month stage

\begin{tabular}{|c|c|c|c|c|c|}
\hline Somaclones & $\begin{array}{c}\text { Number of days for } \\
\text { sprouting }\end{array}$ & Plant height (cm) & Number of tillers per plant & Number of leaves per shoot & $\begin{array}{l}\text { Leaf area } \\
\qquad\left(\mathrm{cm}^{2}\right)\end{array}$ \\
\hline SE 8626 & 16.33 & 87.37 & 18.01 & 28.33 & 55.14 \\
\hline SE 8683 & 16.67 & 84.50 & 15.63 & 17.25 & 48.08 \\
\hline C 8626 & 23.33 & 85.47 & 14.83 & 16.43 & 43.60 \\
\hline CHP 118 & 18.67 & 90.34 & 20.33 & 28.67 & 51.74 \\
\hline C 78284 & 18.33 & 75.42 & 15.27 & 21.00 & 50.63 \\
\hline SE 86102 & 16.00 & 107.38 & 15.13 & 18.23 & 42.09 \\
\hline SE 8642 & 20.67 & 80.20 & 17.97 & 26.33 & 58.46 \\
\hline C 8632 & 18.33 & 87.55 & 16.93 & 26.07 & 62.12 \\
\hline CHP 99 & 23.67 & 82.02 & 11.23 & 16.87 & 37.43 \\
\hline CHP282 & 21.00 & 92.23 & 15.01 & 16.93 & 52.56 \\
\hline Rio-de-Janeiro & 16.33 & 83.52 & 11.56 & 17.89 & 41.38 \\
\hline Himachal & 15.33 & 92.07 & 11.43 & 17.88 & 41.88 \\
\hline Aswathy & 13.67 & 72.55 & 14.93 & 20.20 & 43.25 \\
\hline CD (0.05) & 2.71 & 5.52 & 0.83 & 1.77 & 2.96 \\
\hline
\end{tabular}




\section{Int.J.Curr.Microbiol.App.Sci (2018) 7(10): 1409-1415}

Table.3 Rhizome characters of ginger somaclones

\begin{tabular}{|c|c|c|c|c|c|c|c|}
\hline \multirow{2}{*}{ Somaclones } & \multicolumn{2}{|c|}{ Number of fingers } & \multicolumn{3}{|c|}{ Weight of fingers (g) } & \multicolumn{2}{|c|}{ Fresh yield } \\
\hline & Primary & Secondary & Mother & Primary & Secondary & Yield / plant (g) & Yield / plot (kg) \\
\hline SE 8626 & 4.33 & 10.06 & 9.67 & 15.07 & 13.20 & 266.67 & 8.54 \\
\hline SE 8683 & 3.33 & 7.33 & 7.43 & 11.40 & 8.20 & 145.33 & 4.65 \\
\hline C 8626 & 3.33 & 6.33 & 8.10 & 10.47 & 7.47 & 201.93 & 6.48 \\
\hline CHP 118 & 4.83 & 10.33 & 10.67 & 14.80 & 11.21 & 274.13 & 8.77 \\
\hline C 78284 & 3.01 & 8.67 & 8.80 & 11.07 & 8.43 & 209.67 & 6.51 \\
\hline SE 86102 & 2.98 & 7.67 & 6.03 & 8.10 & 7.42 & 176.47 & 5.65 \\
\hline SE 8642 & 3.98 & 8.33 & 11.00 & 15.73 & 12.33 & 251.67 & 8.06 \\
\hline C 8632 & 4.08 & 10.01 & 9.23 & 14.01 & 10.40 & 259.67 & 8.31 \\
\hline CHP 99 & 2.52 & 6.00 & 7.90 & 11.13 & 7.10 & 131.53 & 4.21 \\
\hline CHP282 & 3.33 & 6.00 & 6.27 & 11.30 & 6.33 & 206.27 & 6.60 \\
\hline Rio-de-Janeiro & 3.67 & 8.33 & 5.60 & 11.28 & 8.87 & 196.67 & 6.29 \\
\hline Himachal & 3.33 & 8.67 & 7.83 & 10.43 & 9.10 & 187.73 & 6.01 \\
\hline Aswathy & 3.42 & 8.67 & 7.80 & 11.43 & 8.17 & 201.20 & 6.43 \\
\hline CD (0.05) & 0.75 & 1.22 & 0.52 & 1.25 & 1.08 & 29.71 & 1.05 \\
\hline
\end{tabular}


Leaf area influences the photosynthetic efficiency of plants. The somaclone C 8632 recorded the highest leaf area $\left(62.12 \mathrm{~cm}^{2}\right)$ at six month stage followed by SE $8642\left(58.46 \mathrm{~cm}^{2}\right)$ and SE $8626\left(55.14 \mathrm{~cm}^{2}\right)$. These results are comparable with the findings of Surendra Babu et al., (2017), where the leaf area per plant in ginger varieties ranged from $\left(22.88 \mathrm{~cm}^{2}\right)$ to $\left(32.47 \mathrm{~cm}^{2}\right)$ which might be due to the differences in leaf length and width as the age of the plant advances and due to environmental conditions.

\section{Rhizome characters}

Variability in rhizome characters such as number of primary and secondary rhizomes, weight of mother rhizome, weight of primary and secondary rhizomes and rhizome yield per plant, plot and hectare observed at full maturity is presented in Table 3.

There was significant difference among the somaclone on the number of primary rhizomes and the highest value (4.83) was recorded by the CHP 118 and was on par with SE 8626 (4.33) and C 8632 (4.08). The number of secondary rhizomes was also found maximum for CHP 118 with a value of 10.33 and was on par with SE 8626 (10.06) and C 8632 (10.01). The weight of mother rhizome varied from 5.60 to 11.00 grams among the somaclones. The highest value $(11.00 \mathrm{~g})$ was for the somaclone SE 8642 and it was on par with CHP 118 (10.67g).

Lowest mother rhizome weight $(5.60 \mathrm{~g})$ was recorded in Rio-de-Janeiro. The average weight of primary rhizome showed significant variation among the somaclones and the highest value $(15.73 \mathrm{~g})$ was recorded for SE 8642 and was on par with SE 8626 (15.07 g) and CHP 118 (14.80 g) followed by C 8632 (14.01 g). SE 86102 recorded lowest value $(8.10 \mathrm{~g})$ for this character. The highest value $(13.20 \mathrm{~g})$ for secondary rhizome was recorded for SE 8626 which was on par with SE 8642 (12.33 g) and the lowest was for CHP $282(6.33 \mathrm{~g})$. Such variation with respect to rhizome characters has been reported earlier by Chongtham et al., (2013) and Dev (2013).

Significant difference was observed among somaclones for yield characters recorded at full maturity stage (Table 3). The highest fresh rhizome yield per plant (274.13 g) was recorded by somaclone CHP 118 which was on par with SE $8626(266.67 \mathrm{~g}), \mathrm{C} 8632(259.67 \mathrm{~g})$ and SE $8642(251.67 \mathrm{~g})$ at harvest.

The highest yield per plot $(8.77 \mathrm{~kg})$ was recorded by somaclone CHP 118 on par with SE $8626(8.54 \mathrm{~kg}), \mathrm{C} 8632(8.31 \mathrm{~kg})$ and SE $8642(8.06 \mathrm{~kg})$. Per hectare yield was found maximum for the somaclone CHP $118(35.08 \mathrm{t})$, SE 8626 (34.16 t), C 8632 (33.24 t) and SE 8642 (32.24 t) compared to other somaclones and check varities (Fig. 1). The higher yield obtained in these ginger somaclones are due to higher number of tillers and rhizomes and also due to higher weight of rhizomes.

The rhizome yield of ginger is an outcome of good rhizomes characters such as number and weight of primary and secondary and mother rhizome as reported by Sangeetha and Subramanian (2015). In the present study, 60 per cent of the somaclones yielded higher than check varieties and the highest yield increase was 140 percentage. This is also in accordance with the study of Kankanawadi (2015) who reported variability in rhizome yield in ginger somaclones. Superiority of somaclones over conventionally propagated plants for rhizome characters and yield was reported by Dev (2013) and Resmi and Shylaja (2012).

The present study concluded that somaclones were highly variable in their performance, yield and yield attributes. Among the somaclones studied, CHP 118 showed significant performance followed by SE 8626, C 8632 and SE 8642 with respect to growth and yield parameters compared to other somaclones and check varieties. They can be rated as the best among the somaclones since they possess the highest rhizome yield and found suitable for cultivation. Yield contributing attributes may be 
taken care of in a variety for obtaining high yield.

\section{References}

Chongtham, T., Chatterjee, R., Hnamte, V., Chattopadhyay, P.K. and Khan, S.A. 2013. Ginger (Zingiber officinale Rosc.) germplasm evaluation for yield and quality in southern West Bengal. J. Spices Arom. Crops 22: 88-90.

Dev, A. 2013. Characterization and evaluation of somaclones of ginger (Zingiber officinale Rosc.). M.Sc. (Hort.) thesis, Kerala Agricultural University, Thrissur, $112 \mathrm{p}$.

Dev, A., Kurian, A. and Sankar. M.A. 2016. Yield attributes and yield in somaclones of ginger (Zingiber officinale Rosc.). $J$. Spices Aromat. Crops 25 (1): 49-55.

Iwo, G.A., Uwah, D.F. and Uko, A.E. 2011. Variation in agronomic performance and proximate composition of some ginger genotypes in humid agro-ecology of Nigeria. J. Agriculture, Biotechnology and Ecology. 4(1): 13-18.

Kankanawadi. A. 2015. Screening of somaclones of ginger (Zingiber officinale Rosc.) for value addition. M.Sc. (Hort.) thesis, Kerala Agricultural University, Thrissur, 104p.

Karthik C. S., Venugopal, S., Pariari A., Nuthana G., Manjesh G.N. and Chandrashekhar, G. 2017. Evaluation of Ginger (Zingiber officinale rosc.) Germplasm for Its Growth and Yield in Gangetic Alluvial Plains of West Bengal. Int. J. Agri. Sci. 9(9): 3948-3950.
KAU (Kerala Agricultural University). 2011. Package of Practices Recommendations: Crops (14 ${ }^{\text {th }}$ Ed.). Kerala Agricultural University, Thrissur, pp. 121- 123.

Kurian, A. 2010. Final report of the DBT funded project. Induction of variation in vitro and screening for resistance to diseases and quality in ginger (Zingiber officinale Rosc.), Kerala Agricultural University, Vellanikkara p. 39

Resmi, P. and Shylaja, M.R. 2012. Field evaluation of tissue culture-raised somaclones of ginger (Zingiber officinale Rosc.) for productivity-linked traits. $J$. Med. Aromat. Plant Sci. 34(1/2): 20-17.

Sangeetha, K. S. and Subramanian, S. 2015 Evaluation of ginger (Zingiber officinale Rosc.) genotypes under coconut ecosystem. The Bioscan 10: 1925- 1928 .

Shadap, A., Hegde, N.K. and Pariari, A. 2013. Performance of ginger var. humnabad as influenced by planting dates under northern dry zone of Karnataka. The Bioscan. 8(1): 131-133.

Shylaja, M.R.., Paul, R.., Nybe, E.V., Abraham. K., Nazeem, P.A., Valsala, P.A. and Krishnan, S. 2010. Two ginger varieties from Kerala Agricultural University. Indian J. Arecanut Spices Med. Plant. 12: 3- 4.

Surendra Babu, M.B. Prasanna Kumar, D.V. Swami, K. Uma Krishna and Emmanuel, N. 2017. Performance of ginger (Zingiber officinale Rosc) varieties under shade net condition of costal Andhra Pradesh. Int. J. Curr. Microbiol. App. Sci. 6(7): 494-498.

\section{How to cite this article:}

Nimisha Mathews and Krishnakumary, K. 2018. Screening Somaclones of Ginger (Zingiber officinale Rosc.) for Yield Attributes and Yield. Int.J.Curr.Microbiol.App.Sci. 7(10): 1409-1415. doi: https://doi.org/10.20546/ijcmas.2018.710.156 